\title{
MERCOSUR, UNASUR AND BRAZILIAN DIPLOMATIC MEASURES FOR THE PREVENTION AND FIGHTING OF ILLICIT TRAFFICKING OF CULTURAL PROPERTY: PURPOSES, STRATEGIES AND ACTIVITIES OF THE RECENTLY CREATED MULTILATERAL AND NATIONAL SPECIALIZED COMMITTEES
}

MEDIDAS DO MERCOSUL, UNASUL E DIPLOMÁTICAS BRASILEIRAS PARA PREVENIR E COMBATER O TRÁFICO ILÍCITO DE PROPRIEDADE CULTURAL: PROPÓSITOS, ESTRATÉGIAS E ATIVIDADES DOS COMITÊS ESPECIALIZADO MULTILATERAL E NACIONAL RECENTEMENTE CRIADOS

\begin{abstract}
ANAUENE DIAS SOARES
Consultora da UNESCO para o Tráfico llícito de Bens Culturais; Perita (Receita Federal do Brasil) e Restauradora de Obras de Arte; Advogada e Consultora Jurídica - Direito das Artes e do Patrimônio Cultural; Mestre em Ciências (USP); Especialista em Direito Internacional (CEDIN); Especialidade em Restauração de Bens Culturais (UPV - Espanha); Bacharel em Direito (PUCCAMP) e Graduada em Artes Visuais (USP); anauene@usp.br
\end{abstract}

LUIZ GUILHERME PIAGENTINI Mestrando em Direito Internacional (USP); Bacharel em Ciências Jurídicas (USP) e advogado do Lazzarini Moretti Advogados; luiz.piagentini@gmail.com. 


\section{ABSTRACT}

The illicit trafficking of cultural property is a reality in most South American countries. For years, although cultural diplomacy has evolved in the national and multilateral spheres, no significant concrete measures have been taken to fight the illicit trafficking, which has kept developing even after the 1970 UNESCO Convention. In that context, two recent initiatives seem to promote new perspectives. The Mercosur-Unasur Technical Committee for the Prevention and Fighting of Illicit Trafficking of Cultural Property establishes a multilateral dialogue in the field, fostering respect and promotion of the cultural diversity in the region. The Brazilian National Committee for the Fighting of Illicit Trafficking of Cultural Property, which still has not been institutionalized, intends to be a discussion venue in the field, establishing a multi-stakeholder approach in the national level. The main challenges that will be faced by both committees concern the implementation of concrete measures within South American source countries, as well as possibly exercising pressure to induce market-end states to adopt the necessary reforms to fight the illicit trafficking of cultural property.

KEYWORDS: Cultural diplomacy; Mercosur; Unasur; illicit trafficking of cultural property.

\section{RESUMO}

O tráfico ilícito de bens culturais é uma realidade na maioria dos países sulamericanos. Durante anos, embora a diplomacia cultural tenha progredido nas esferas nacional e multilateral, não foram tomadas medidas concretas significativas para combater o tráfico ilícito, o qual continuou se desenvolvendo mesmo após a Convenção da UNESCO de 1970. Nesse contexto, duas iniciativas recentes parecem promover novas perspectivas. O Comitê Técnico para a Prevenção e o Combate ao Tráfico llícito de Bens Culturais do Mercosul-Unasul estabelece um diálogo multilateral sobre o tema, impulsionando o respeito e a promoção da diversidade cultural na região. O Comitê Nacional de Combate ao Tráfico llícito de Bens Culturais, que ainda não foi institucionalizado, pretende ser um foro de discussão sobre o tema, 
estabelecendo uma abordagem a partir da participação de diversos atores em nível brasileiro. Os principais desafios que ambos os comitês terão de enfrentar consistem na implementação de medidas concretas nos países de origem sul-americanos, bem como possivelmente o exercício de pressão para induzir países destinatários do mercado final de bens culturais a adotar as reformas necessárias para combater o tráfico ilícito de bens culturais.

PALAVRAS-CHAVE: Diplomacia cultural; Mercosul; Unasul; tráfico ilícito de bens culturais.

\section{INTRODUCTION}

The illicit trafficking of cultural property is a crude reality in South America. History testifies that throughout centuries, as of the colonial period in the region, cultural property appertaining to the native communities that lived in the territory has been either destroyed, or looted and traded in the international market. Until the first half of the twentieth century, the looted artifacts were mostly purchased by diplomats and foreign business agents located in source countries. However, the problem has evolved to a critical dimension as long as a real international market for native American antiquities has been established (YATES, 2015, p. 37).

Although the second half of the twentieth century has inaugurated a new perspective with regards to cultural property protection, with the emergence of international conventions and agreements on the subject - notably the 1970 UNESCO Convention -, no significant impact seems to have been observed in the looting and illicit trade practices in South America (YATES, 2015, p. 40). Consequently, the international market for South American cultural property kept developing, as to encompass not only the so-called pre-Columbian artifacts, but also sacred and religious objects from the colonial period in the region, as well as modern and contemporary art. New issues, therefore, started to arise, such as money laundering practices, notably in the context of the illegal commerce of modern and contemporary 
artworks, which have important repercussions both in the national and international levels (including normative and regulatory initiatives, as the Brazilian IPHAN/CNART Resolution n. 396/2016, on the proceedings that shall be complied with by art and antiquities dealers).

Considering such reality and the international legal issues arising therefrom, the main purpose of this article is to present and analyze the diplomatic measures that are been taken in the South American context in order to fight the illicit trafficking of cultural property. The article will be based on the evaluation of how the strategies recently adopted by Mercosur and Unasur, as well as in the Brazilian context, are being or may potentially be effective in the implementation of the international rules for the protection of cultural heritage and cultural property.

In order to fulfill these research objectives, documentary research has been done, notably encompassing primary sources, such as international conventions, declarations, diplomatic notes, administrative measures and resolutions of international and regional organizations. Bibliographic research has also been done, referring to secondary sources, especially to academic work of the most qualified scholars in the fields of international law, multilateral relations, cultural diplomacy and cultural property protection.

In that sense, as to address the topic, the article will be divided into two chapters. In a first chapter we will analyze the development of cultural diplomacy in Mercosur and in Brazil throughout time, emphasizing the respective issues that have been historically dealt with, and contextualizing how the challenge regarding the illicit trafficking of cultural property emerged within the respective agendas and discussions.

Taking into consideration this broad context in the cultural diplomacy field, we will then, in a second chapter, examine the recent multilateral initiative regarding the subject in the sphere of Mercosur and Unasur, with the creation of a specialized technical committee to deal with the illicit trafficking of cultural property, as well as the institutionalization of a Brazilian national committee for the same purpose.

Finally, we will draft a conclusion, verifying the relevance and the effectiveness of the analyzed instruments and mechanisms, concerning cultural heritage protection 
and the fighting of illicit trafficking of cultural property within the South American context.

\section{THE FOUNDATIONS OF CULTURAL DIPLOMACY IN MERCOSUR, UNASUR AND IN BRAZIL: CHALLENGES WITH REGARDS TO THE ILLICIT TRAFFICKING OF CULTURAL PROPERTY}

Cultural diplomacy within Mercosur is a relatively recent construction. The first reference to Mercosur cultural was expressly made only in 1995. In the case of Unasur, cultural initiatives date back to 2012. In Brazil, although there were some cultural incursions in foreign policies in the nineteenth century, it has only been consolidated throughout the twentieth century.

The present chapter will present, in a first section, a brief historical overview on the development of cultural diplomacy in the region, with special emphasis on the Brazilian experience, on the evolving Mercosur institutions towards culture and on the Unasur initiatives. Then, a second section will focus on the challenges faced by cultural diplomacy in the region, regarding the illicit trafficking of cultural property, and the protection of cultural heritage, how they have emerged as core issues in the agenda of both regional and national institutions, and how they require measures to be addressed under cooperation between both instances.

\subsection{THE DEVELOPMENT OF A CULTURAL AGENDA IN MERCOSUR, UNASUR} AND BRAZIL

Cultural diplomacy in South America is still an issue that requires greater and broader development, in order to comply with its purposes and achieve its main objectives. The history of diplomatic initiatives towards culture is relatively recent in the region, notably in the multilateral level.

In the context of Mercosur, although some prior initiatives could be considered as predecessors of a regional cultural diplomacy (HARVEY, 2001, p. 8), in its founding 
document, the Treaty of Asunción (1991), there were no mentions to cultural issues, nor to educational, scientific and technological development. Only commercial aspects were considered, in order to establish a common market within South American countries. The first cultural initiative in Mercosur was the creation of the Specialized Meeting on Culture, established by the Resolution n. 34/92, of the Common Market Group (SOARES, 2008, p. 59). The idea was to promote the culture of the states parties, stimulating cooperation and regional activities in the cultural sphere. In 1995, a greater step was taken, with the institutionalization of a Meeting of Cultural Ministers of the States Parties, as a negotiating venue regarding cultural issues, replacing the Specialized Meeting.

Although by the time of its foundation the Meeting of Cultural Ministers had been seen with optimism, no significant measures were taken, and no important regional cultural policies were established. The technical commissions of the Meeting, related to cultural heritage, cultural industries, information networks and capacitybuilding, had no relevant results other than those regarding legislation (SOARES, 2008, p. 60).

In 1996, a more important measure was taken, with the promulgation of the Mercosur's Cultural Integration Protocol. It establishes the fundaments of a cultural diplomacy in the region, especially highlighting, in article I, the cooperation among the States parties in what concerns all their cultural agencies and institutions, in order to promote the enrichment and diffusion of the diverse cultural and artistic expressions in the region. In the same direction, in article VI, the Protocol emphasizes the need of cooperation among museums, national and historic archives and libraries, in order to harmonize the criteria for classification, registering and preservation of cultural property of the States parties.

However, the Cultural Integration Protocol also lacks efficiency in the promotion of cultural policies within Mercosur. Notwithstanding the responsibilities undertaken by the States Parties to cooperate for actively establishing the regional cultural integration, no concrete measures seem to be taken. The Protocol does not set forth real actions that shall be taken, but only abstract cooperation duties that do not satisfy the needs for the implementation of a cultural policy. 
With respect to Unasur, the development of a cultural diplomacy is even more recent than in Mercosur. It was only in 2012, in the occasion of the $6^{\text {th }}$ Unasur Meeting of Heads of State and Government, that the South American Council of Culture was created. The Council is charged of the promotion and strengthening of the cultural cooperation in the region, of the recognition and promotion of the central value of culture as a core feature in the development process and in overcoming poverty and inequality, as well as of the reduction of regional and sub-regional asymmetries with regards to the access to culture (SOARES, 2018, p. 91).

According to its mission, the South American Council of Culture recognizes cultural heritage as a founding condition for the establishment of a regional identity, and for the resistance to hegemonic cultural practices. In addition, the Council, via its Statute, also urges for the promotion, recognition, protection, safeguarding and social appropriation of the natural and cultural heritage, either tangible or intangible, as well as of all the diversity of cultural expressions of the peoples living in the states parties to Unasur.

Complying with its mission, the Council has also created a work group on illicit trafficking of cultural property, with the purpose of strengthening the international cooperation through return, restitution and repatriation of cultural property illegally exported, or that has been the object of any form of crime, such as theft, plunder or money laundering (SOARES, 2018, p. 91-92).

In Brazil, the cultural diplomacy has a long history, notably throughout the twentieth century. Until the nineteenth century, although there were Brazilian foreign policies related to culture, these were restricted to the literary issues and to official visits of foreign intellectuals. It was only in the aftermath of the First World War that a cultural diplomacy has been consolidated by Brazilian authorities - pioneering the discussions on the field within the Latin American context (DUMONT \& FLÉCHET, 2014, p. 204).

From the 1920 s to 1945 , cultural diplomacy could be defined by three central aspects: (i) institutional disorder, (ii) pragmatism in dealing with the issues, policies and their addressees, and (iii) dissociation between culture that was appreciated inside the country, and the Brazilian culture that was broadcast in international level (DUMONT 
\& FLÉCHET, 2014, p. 209). Thereafter, from 1945 to 1980, Brazilian cultural diplomacy was transformed and institutionalized though the successive reforms of the Ministry of Foreign Affairs.

Nowadays, the three main objectives pursued by Brazilian cultural diplomacy are the promotion of Brazilian culture and Brazilian arts worldwide, the establishment of cultural cooperation policies and the encouragement of Portuguese language learning. In order to achieve those goals, initiatives are currently taken by a relevant group of public organs. The Cultural Department of the Ministry of Foreign Affairs leads the cultural diplomacy initiatives in Brazil, operating through five main units: Division for Portuguese Language Promotion (Divisão de Promoção da Língua Portuguesa), Division for Cultural Diffusion Operations (Divisão de Operações de Difusão Cultural), Division for Audiovisual Promotion (Divisão de Promoção Audiovisual), Division for Agreements and Multilateral Cultural Affairs (Divisão de Acordos e Assuntos Multilaterais Culturais) and Division for Educational Themes (Divisão de Temas Educacionais).

However, the extent and the efficiency of cultural measures taken by the Brazilian Ministry of Foreign Affairs is still questioned and considered insufficient to deal with the challenges that it has to face (CRUZ, 2017; SOARES, 2008).

\subsection{COMMON CHALLENGES FOR MERCOSUR, UNASUR AND BRAZILIAN CULTURAL DIPLOMACY: THE ILLICIT TRAFFICKING OF CULTURAL PROPERTY AND THE PROTECTION OF CULTURAL HERITAGE}

Considering that, notwithstanding Mercosur and Unasur initiatives with respect to cultural diplomacy, cultural integration in the context of South American region is still incipient, two main articulated challenges seem to arise, requiring the attention and cooperation of both multilateral and national organisms: the illicit trafficking of cultural property and the protection of cultural heritage.

Discussions about cultural heritage are a relevant issue in the Latin American region since the colonization period. The devastation of the native cultures that was observed during the Spanish and Portuguese occupations of the continent evidences 
a violence against heritage without precedents. In the Hispanic America, entire civilizations were obliterated, much of their intangible cultural heritage was lost, and many material expressions of their respective cultures were also destroyed. Similarly, in Brazil the same kind of violence was perpetrated against indigenous peoples, and for a long time continued to exercise its effects due to the lack and insufficiency of preservation measures (FUNARI, 2001, p. 4).

Taking into account this historical context, the protection of cultural heritage arises as a fundamental issue that needs to be dealt with in the region, both in national and multilateral spheres, notably considering that few cultural heritage expressions have survived the centuries. In the legal field, most South American countries have established some sort of regulation regarding cultural heritage protection ${ }^{1}$, notably claiming ownership of archaeological objects and prohibiting digging and exporting of artifacts without permission (YATES, 2015, p. 36). However, the circulation of cultural property is still a great challenge, since the regional reality evidences that such circulation is substantially developed via illegal venues:

Because most Latin American countries outlawed the export of antiquities before an international market grew for them, all the Latin American antiquities on the market were tainted by crime and were illegal in some jurisdictions. This is still the case (YATES, 2015, p. 37).

The illicit trafficking of cultural property in the context of Latin America has two main focuses. The first one, evidently, corresponds to the archaeological artifacts of the native civilizations of the region, encompassing ceramics, metalwork, textile, stonework and figurines. The second one concerns pieces of sacred art of the colonial period, notably silverwork, icons, figures, sculptures, paintings, bells and furniture (YATES, 2015, p. 34-36).

Before the 1970 UNESCO Convention, looting was already a reality in the context of Latin American countries:

\footnotetext{
${ }^{1}$ All Mercosur countries have adopted some sort of norms regulating and protecting culture and heritage. For further details on each country respective legislation, please consult: http://sicsur.mercosurcultural.org/legislacion.html
} 
It is difficult to put an exact date on the start of looting in Latin America and various activities of the late 1800 s could be considered looting. However, after the early 1900s, true scientific archaeology was conducted in Central and South America by both foreign and local scholars and after about 1925, particularly in Peru, scholars reporting that sites were being looted and objects were coming up for sale on the market in their country of origin (Tello 1959). Some of this early looting was devastating, for example the looting of the Paracas Necropolis for textiles from 1931 to 1933, but truly endemic looting came later. At this time the market for these objects was local or international in a local way: the objects were purchased in-country by foreign diplomats and business people (YATES, 2015, p. 36).

This local market was in great part developed by locals that, due to multiple structural reasons - which can be notably related to the poverty of local communities, to dealers' wit and to the pressure, within the chain, exercised by wealthy collectors (BOKOVA, 2013, p. 3) -, were induced to sell information about cultural heritage sites to middlemen, or to loot themselves the sites and sell the artifacts to such men. These intermediaries, located in the source country, would provide the transport and exportation of the looted objects, also using their influences within the local corruption to promote the circulation. After that, in the receiving countries, other middlemen would be in charge of creating a false provenance, a plausible back story for the artifacts, so that they could be unsuspiciously sold in the legitimate market (YATES, 2015, p. 37).

However, a real international market for these Latin American artifacts was organized only after 1970, and has developed in a vigorous pace since then, particularly with respect to pre-Colombian artifacts:

In Latin America, the bleeding of cultural property has attained in some preColombian sites disquieting proportions, and the importance of organized trafficking is so vast that it has acquired a global economic dimension (BOKOVA, 2013, p. 3) $)^{2}$.

The 1970 UNESCO Convention does not seem to have had significant impact on the illicit trafficking of cultural property within Latin America. Looting has even increased in some regions. In addition, the theft of sacred art has accentuated in the

\footnotetext{
${ }^{2}$ Free translation. Original in Spanish: "En América Latina, la hemorragia de bienes culturales ha alcanzado em algunos sitios precolombinos proporciones inquietantes, y la importancia del tráfico organizado es tal que ha adquirido una dimensión económica mundial".
} 
1990s and 2000s (YATES, 2015, p. 40) - and it is still an understudied criminal practice in the region.

In what concerns the South American continent, this reality is also reflected. Mercosur and Unasur shall in that sense work in the multilateral level, cooperating with the diplomacy of the states of the region, to fight the illicit trafficking of cultural property - acknowledging that it is not an isolated problem, but rather one that is intrinsically related to structural deficiencies from which South America still suffers, notably considering social inequalities, generalized corruption, political instability, as well as other criminal activities such as narcotrafficking and people trafficking (YATES, 2015, p. 42).

In such context, the recent initiatives taken by Mercosur/Unasur and by Brazilian authorities, that will be presented in the following chapter, seem to be of great importance, and can possibly provide us with some answers, in the medium term.

\section{THE MULTILATERAL AND NATIONAL INITIATIVES TO FIGHT THE ILLICIT TRAFFICKING OF CULTURAL PROPERTY: MERCOSUR/UNASUR AND BRAZILIAN COMMITTEES}

Considering the context of the cultural diplomacy in South America, as well as the reality regarding the illicit trafficking of cultural property in the region, it is undeniable that the measures and strategies to fight the problem cannot be unilateral, but rather need a compromise by the plurality of involved states (FABRIS, 2017, p. 196)

Taking this into consideration, two important initiatives have been taken - one in the multilateral level, with the establishment by Mercosur and Unasur of a regional committee for the fighting against the illicit trafficking, and the other within Brazilian diplomacy, via the creation of national committee in the field.

In the present chapter, our analysis will be devoted to such initiatives. In a first section, we will address the multilateral initiative, emphasizing its foundation and 
conception, as well as its main activities. In a second section, the focus will be on the national committee, analyzing its institutionalization, as well as the intended activities.

\subsection{MERCOSUR AND UNASUR'S TECHNICAL COMMITTEE FOR THE PREVENTION AND FIGHTING OF THE ILLICIT TRAFFICKING OF CULTURAL PROPERTY}

The South American Council of Culture approved the creation of the Technical Committee for the Prevention and Fighting of the Illicit Trafficking of Cultural Property, which objective is to establish a cooperation between Mercosur and Unasur in the field. The Committee was institutionalized during the Forth Meeting of the South American Council of Culture, in March 2017, with the participation of Argentina, Bolivia, Brazil, Colombia, Ecuador, Uruguay and Venezuela.

In accordance with the declaration issued during the meeting, the participating countries recognized that culture constitutes a fundamental axe for the construction of a world of plurality, diversity and peace, since it strengthens people's distinct capacities and human values, being one of the main factors that can contribute to the sustainable development of communities, peoples and nations. They also reiterate that all cultures constitute the heritage of mankind, and undertake to contribute for the universal access to cultural rights, which are considered essential human rights ${ }^{3}$.

In the First Meeting of the Technical Committee for the Prevention and Fighting of the Illicit Trafficking of Cultural Property, held on October 25, 2017, in which have participated Argentina, Bolivia, Brazil, Colombia, Ecuador, Paraguay, Peru and Uruguay, as well as Mercosur Cultural representatives, a plan of action has been discussed, for the years of 2017 and 2018, according to information reported by the Brazilian Ministry of Culture (SOARES, 2018, p. 94).

The states that participated to the meeting agreed on the necessity to develop further work tools to permit a faster articulation between competent institutions on the

\footnotetext{
3 Declaración de las Ministras y Ministros de Cultura de los Estados Miembros de Unasur. Cuarta Reunión del Consejo Suramericano de Cultura. Mitad del Mundo, Ecuador, 31 de marzo de 2017.
} 
fighting of illicit trafficking of cultural property. For instance, they have mentioned informatic tools, alert systems, and sharing of information in real time. They have also agreed on the organization of capacity-building course in Peru, in 2018, supported by FBI, legitimizing the partnership between Peru and the United States. On its turn, Argentina provided a database of stolen cultural property in order to inscribe the respective information in Interpol database (SOARES, 2018, p. 94).

Furthermore, in this first meeting, the Mercosur-Unasur Committee also established some proposals in order to prevent and fight the illicit trafficking of cultural property. The first of these proposals was to enhance the internal communication proceedings, among the national organs charged of the prevention and fighting of the illicit trafficking of cultural property, in order to increase the efficiency of the nationally adopted measures, and to minimize the international trafficking. The second proposal was to reaffirm the interesting in enhancing the communication and sharing of information among the South American countries, emphasizing methodology development, in order to promote more efficient cooperative actions. Finally, the third proposal concerned the facilitation of access to some information and databases regarding the illicit trafficking of cultural property by Peru and by the Brazilian Institute of National Historic and Artistic Heritage (IPHAN) (SOARES, 2018, p. 95).

Considering the challenges mentioned in the preceding chapter, it is undeniable that the Mercosur-Unasur Committee, with the objectives that it has undertaken, can potentially exercise an extraordinary role in fighting the illicit trafficking of cultural property within the South American countries. Nevertheless, it will be of high importance that the measures proposed in the first meeting be complied with, effectively promoting a faster and greater level of communication among the states. It will also be crucial that in the subsequent meetings, the committee undertakes to promote more concrete measures, such as how it can contribute to the enforcement of multilateral regulations and national regimes regarding the protection of cultural heritage and the fighting of the illicit trafficking.

Moreover, it will be of indisputable relevance that the Mercosur-Unasur Committee consider the challenge of fighting the illicit trafficking of cultural heritage not from an isolated point of view, but from a broader perspective, that takes the structural 
problems and deficiencies of the region into account - so that it can propose more coherent and effective solutions.

\subsection{BRAZILIAN NATIONAL COMMITTEE FOR THE FIGHTING OF ILLICIT TRAFFICKING OF CULTURAL PROPERTY (COMITÊ NACIONAL DE COMBATE AO TRÁFICO ILÍCITO DE BENS CULTURAIS)}

In Brazil, the issues related to the illicit trafficking of cultural property are also posed, notably in what concerns cultural artifacts appertaining to the traditions of indigenous tribes, and also regarding sacred objects from the colonial period.

Similarly to what happened in most Latin American states, many of Brazilian native cultural artifacts left the country through diplomatic venues - by the purchase by or gifting to foreign agents, especially throughout the colonial and empire periods, when there were no national regulations protecting heritage. Notwithstanding, in many other cases, Brazilian cultural property has also been subject to pillage and theft.

In this context, even though Brazil had already consolidated a cultural diplomacy department in the Ministry of Foreign Affairs during the twentieth century, there were no institutionalized diplomatic initiatives targeting the illicit trafficking of cultural property - which is an international issue by nature. As a consequence, many Brazilian cultural artifacts that nowadays lie in foreign collections, and that could be legitimately claimed for restitution, receive no attention from the competent authorities. An emblematic case was that of the Tupinambá mantle. The Tupinambás were an ethnic native Brazilian group, which had a traditional mantle, used for rituals, made of plumage of native species of birds. During the colonial period, as the tribe was extinct, these mantles were brought to Europe, where all the six remaining ones are still located. In 2000, in the occasion of an exhibition celebrating the five hundred years of the discovery of Brazil by Portugal, one of these mantles was lent by the Nationalmuseet, from Copenhagen, Denmark. In such occasion, a group of indigenous people decided to claim for the restitution of the mantle, alleging that it was important for their identity, as it had belonged to their ancestors. However, until nowadays, any negotiation has been undertaken, neither any diplomatic initiative, for the repatriation 
of the piece (BORGES \& BOTELHO, 2010), which 'naturally' came back to Denmark after the end of the exhibition.

Considering this overview, a recent initiative of the Brazilian Ministry of Culture aims to intervene in the field, with the creation, within Brazilian government, of a National Committee for the Fighting of the Illicit Trafficking of Cultural Property. Although the formal institutionalization of the committee has not yet taken place, some preliminary meetings have already been organized. The main idea is to promote a national coherent strategy to fight the illicit trafficking of cultural property.

In accordance with the International Promotion Department of the Ministry of Culture, in order to achieve effective results in the battles against the illicit trafficking of cultural property, it is required that a coordinate action be taken, through cooperation of the multiple stakeholders that exercise a relevant role in the field ${ }^{4}$. That is why the initiative of the national committee will involve many organs and agencies within Brazilian public administration: the International Promotion Department of the Ministry of Culture, the International Promotion Department of the National Library Foundation (FBN), the Brazilian Institute of Museums (Ibram), the Institute of the National Historic and Artistic Heritage (IPHAN), as well as representatives of the Federal Police, of the National Archives (of the Ministry of Justice and Citizenship), of the Federal Revenue Department (Secretaria da Receita Federal - Ministério da Fazenda), of the Cultural Department of the Ministry of Foreign Affairs, and of the National Mining Department of the Ministry of Mining and Energy 5 .

The objectives of the national committee shall comprise not only the formulation of an integrated strategy, but also of proceedings and mechanisms of prevention and repression of the illicit trafficking, as well as the creation of a database of cultural property that is reputed lost or in danger. Additionally, the national committee shall also propose and implement capacity building activities to strengthen the fighting of the illicit trafficking and to inform the society about actions taken in the field,

\footnotetext{
4 For more information, please consult the Brazilian Ministry of Culture's website: http://www.cultura.gov.br/noticias-destaques/-/asset_publisher/OiKX3xIR9iTn/content/id/1438818

5 For more information, please consult the Brazilian Ministry of Culture's website: http://www.cultura.gov.br/noticias-destaques/-/asset_publisher/OiKX3xIR9iTn/content/minc-encabecaacao-de-combate-ao-trafico-de-bens-culturais/10883
} 
particularly encompassing conscientization measures about the necessity to protect and preserve local culture, to elaborate inventories of cultural property and to keep them updated.

Being aware of the challenges that have been previously presented, both in the regional and national scales, it seems that the national committee is a great initiative taken by Brazilian government, that can exercise a fundamental role in adopting measures against the illicit trafficking of cultural property. Its main feature will certainly be the multi-stakeholder approach to deal with the issue, providing a coherent strategy, as well as specific targeted actions in each respective field - which can lead to more effective results, provided that concrete measures are drafted and implemented. 


\section{CONCLUSION}

The historical analysis of cultural diplomacy in the South American multilateral level has demonstrated that, even though some important initiatives have been undertaken in the legislative and regulatory fields towards cultural cooperation, significant concrete measures have not yet been implemented.

In the Brazilian context, cultural diplomacy seems to have been institutionalized throughout the twentieth century and is nowadays developed by an entire department of the Ministry of Foreign Affairs, that works in different specialized units to fulfill cultural objectives. Although from the institutional point of view Brazilian cultural diplomacy is well organized (DUMONT \& FLÉCHET, 2014), some authors understand that its actions are not effective in promoting cultural cooperation, arguing that all measures are superficial and do not contribute to concrete changes (SOARES, 2008).

Taking this overview into account, the previous chapters have also evidenced that no consolidated and efficient policies have been built, throughout the past decades, to fight the ever-growing tendencies of the illicit trafficking of cultural property, neither in the multilateral sphere, nor in the national level.

In that context, the recent initiatives taken by Mercosur-Unasur, from the multilateral perspective, and by the Brazilian Ministry of Culture, in the national reality, are unprecedented and reveal their importance to promote the required reforms aiming to fight the illicit trafficking and promote cultural heritage protection, within South America.

The composition of the Mercosur-Unasur Technical Committee for the Prevention and Fighting of the Illicit Trafficking of Cultural Property, encompassing both regional organizations, permits to establish broad initiatives in the field, through the cooperation of all the involved countries. Multilateralism is, therefore, reinforced by the initiative, and helps fostering analytical and practical dialogue within the crossroad of cultures that South America englobes. Its main challenge lies, once again, in the nature of its proposals, that shall be concrete enough to ensure that they will be effectively implemented. 
In addition, the Mercosur-Unasur Committee may also exercise a relevant function in the preservation of cultural diversity in the South American region. By promoting effective actions in the field, it could contribute to (i) reduce the destruction and decontextualization of cultural property, via a more coercive posture towards the illicit trafficking, and (ii) ensure the continuity of local cultural identities, addressing a more protective policy to maintain cultural artifacts in their original communities and environments. For such purposes, the committee should work from an authentic integrating perspective, so that the regional diversity would effectively be respected with no impositions by hegemonic cultures of economically stronger countries (FERNÁNDEZ, 2007, p. 19).

With respect to the initiative of establishing a Brazilian National Committee for the Fighting of Illicit Trafficking of Cultural Property, its main feature is certainly the multi-stakeholder approach that it comprises. By engendering discussions among diverse institutions, agencies and organs that are somehow interested in cultural preservation issues and in the fighting of the illicit trafficking of cultural property, the National Committee may give rise to a comprehensive and coherent strategy in the field, without compromising the respective targeted actions of each stakeholder.

Moreover, the effectiveness of both multilateral and national committees could be even greater in the event both instances agree in contributing with one another, sharing information about their policies and activities, and also promoting joint initiatives. Such cooperation would undoubtedly help reaffirming and projecting Brazilian cultural diversity in the context of South America.

Notwithstanding the importance of these committees, it shall be mentioned that, in order to effectively fight the illicit trafficking of cultural property and make substantial changes in the observed reality of the region, it is also fundamental to take measures in the market end of the trade chain (YATES, 2015, p. 42). Such measures should involve discouraging criminality and punishing criminals, enhancing soft control techniques and adopting object-specific legislation.

Therefore, a new challenge seems to emerge within the role that these committees are intended to assume: how they can contribute to promote, not only more effective measures in the source countries, but also the required structural reforms in 
the market end countries, in order to ensure significant changes in the regional panorama. Could they exercise any kind of pressure to induce such reforms, mostly in developed states? Would they have voice in the international sphere, as institutional bodies that work for the fighting of the illicit trafficking of cultural property? Questions that time will help us answer, as their activities are developed, and their real undertakings are assessed.

\section{REFERENCES}

BOKOVA, Irina. Poner coto al tráfico ilícito de bienes culturales. In SANCHEZ CORDERO, In Jorge A (ed.). La Convención de la UNESCO de 1970, sus nuevos desafíos. UNAM. Mexico, 2013, p. 2. Available at: https://archivos.juridicas.unam.mx/www/bjv/libros/7/3457/3.pdf

BORGES, Luiz Carlos; BOTELHO, Marilia Braz. Museus e restituição patrimonial entre a coleção e a ética. Oral Presentation in the XI National Meeting of Research on Information Science (XI Encontro Nacional de Pesquisa em Ciência da Informação), 2010. Available at: http://enancib.ibict.br/index.php/enancib/xienancib/paper/viewFile/3593/2717

CRUZ, Gizelli Alini da. Mercosul Cultural no Desafio da Integração Sulamericana. Revista Científica Multidisciplinar Núcleo do Conhecimento. Edição 03. Ano 02, Vol. 01. P. 27-36, Jun/2017. ISSN:2448-0959

DUMONT, Juliette; FLÉCHET, Anaïs. "Pelo que é nosso!": a diplomacia cultural brasileira no século XX. Revista Brasileira de História. São Paulo, v. 34, ํo 67, 2014.

FABRIS, Alice Lopes. South-South Cooperation on the Return of Cultural Property: The Case of South America. In: Case Western Reserve Journal of International Law 49 (2017), p. 173-196. Available at: https://scholarlycommons.law.case.edu/cgi/viewcontent.cgi?referer=https://www.goo gle.com.br/\&httpsredir $=1$ \&article $=2505 \&$ context $=$ jil

FERNÁNDEZ, Edgar Gustavo Suárez. Las relaciones culturales em el proceso de integración regional del Mercosur. Academia Nacional de Derecho y Ciencias Sociales de Córdoba (República Argentina). Concurso de Monografías 2007. Available at http://secretarias.unc.edu.ar/acaderc/doctrina/articulos/artrelacionesculturales

FUNARI, Pedro Paulo A. Os desafios da destruição e conservação do Patrimônio Cultural no Brasil. Trabalhos de Antropologia e Etnologia, Porto, 41, 1/2, 2001, 23-32. Available 
https://www.researchgate.net/profile/Pedro_Funari/publication/267403620_OS_DES AFIOS_DA_DESTRUICAO_E_CONSERVACAO_DO_PATRIMONIO_CULTUTAL_N O_BRASIL/links/55dfcd4308aecb1a7cc1a775/OS-DESAFIOS-DA-DESTRUICAO-ECONNSERVACAO-DO-PATRIMONIO-CULTURAL-NO-BRASIL.pdf

HARVEY, Edwin R. El tratado de Asunción y el Mercorsur cultural. Relación con otros procesos de integración regional. Available at: http://www.ufrgs.br/difusaocultural/adminseminario/documentos/arquivo/El\%20tratad 0\%20de\%20Asuncion\%20y\%20el\%20Mercosur\%20Cultural.\%20Relacion\%20con\% 20 otros\%20procesos\%20de\%20integracion\%20regional\%20(Texas\%202001).pdf

MERCOSUR. VIII Reunión de la Comisión del Patrimonio Cultural del MERCOSUR Cultural - CPC. Reunión CPC/Acta n01/2013. Available at: http://portal.iphan.gov.br/uploads/ckfinder/arquivos/Ata_VIII_reuniao_cpc_mercosul_ espanhol.pdf

SOARES, Anauene Dias. Direito internacional do patrimônio cultural: o tráfico Ilícito de bens culturais. Fortaleza: IBDCult, 2018.

SOARES, Maria Susana Arrosa. A diplomacia cultural no Mercosul. Rev. Bras. Polít. Int. 51 (1). P. 53-69 [2008].

UNESCO OFFICE IN MONTEVIDEO. Actores clave de América del Sur unen esfuerzos contra el Tráfico Ilícito de Bienes Culturales. Available at: http://www.unesco.org/new/es/office-in-montevideo/about-this-office/singleview/news/key_players_in_south_america_join_forces_against_illicit_tra/

YATES, Donna. Illicit Cultural Property from Latin America: Looting, Trafficking, and Sale. In F. Desmarais ed. Countering Illicit Traffic in Cultural Goods: The Global Challenge of Protecting the World's Heritage (Paris: ICOM) [2015]. Available at: http://traffickingculture.org/publications/yates-d-2015-illicit-cultural-property-from-latinamerica/ 